\author{
Roberto Martins, Leticia Quinello, Giuliana Souza and Maria Marques
}

\title{
POLYMERIZATION OF ETHYLENE WITH CATALYST MIXTURE IN THE PRESENCE OF CHAIN SHUTTLING AGENT
}

\author{
Instituto de Macromoleculas Eloisa Mano \\ IM A (UFRJ) Cidade Universitaria. Av. Horacio M acedo, \\ 2.030. Centro de Tecnologia. Predio do Bloco J. Rio de Janeiro. RJ. Brasil \\ fmarques@ima.ufrj.br
}

Received: February 10, 2012 / Revised: M arch 01, 2012 / Accepted: M arch 28, 2012

(c) Martins R., Quinello L., Souza G., Marques M., 2012

\begin{abstract}
Mixture of two catalysts in one reactor for ethylene/ $\alpha$-olefin copolymerization in the solution process can result in the combination of microstructures related to both catalysts in the polymer framework. Thus, novel polymer configuration is synthesized, which is characterized by containing sequences of monomers produced with each catalyst in the same polymer chain. Adding a reversible transfer agent (CSA) to the binary system enables the production of new block copolymers with enhanced properties. Late transition metal catalysts, such as $\alpha$-diimine nickel catalyst when activated with methylaluminoxane (MAO) show high activity towards olefin polymerization and produces highly branched homopolymers. On the other hand, $\mathrm{C}_{2}$ symmetry metallocene catalysts produce linear polyethylenes. This paper describes the synthesis of ethylene homopolymer with amorphous and crystalline blocks using a binary mixture containing a nickel catalyst with $\alpha$-diimine ligand, which produces $\phi$ highly branched polyethylene (soft PE) and a metallocene ( $r a c$-ethylene bis $\left(\mathrm{H}_{4}\right.$-indenyl) $\mathrm{ZrCl}_{2}$ ) that converts ethylene into polyethylene with high activities and melting temperatures (hard PE). The influence of polymerization temperature and CSA concentration were investigated. The polymeric materials were characterized by density, thermal properties, X-ray diffractometry and dynamic-mechanical properties.
\end{abstract}

Keywords: ethylene polymerization, single-site catalyst, catalysts mixture, chain shuttling.

\section{Introduction}

Polyolefins are in general commodity type polymers with a wide range of applications [1-4]. It occupies a prominent position in the world market compared to other polymers due to its specific characteristics as: non-toxicity, chemical inertness, good physical and mechanical properties, low production cost and easy availability of raw materials $[5,6]$. It can be found commercially with an incredible variety of properties and applications ranging from ultra-hard (harder and less dense than steel), to high-performance materials such as thermoplastic elastomers [7].

The term elastomer is applied to macromolecular materials that have low modulus and a wide range of elasticity at room temperature [8]. The mechanical properties of elastomers are improved by crosslinking, leading to covalent bonds between the polymer chains. The main commercial elastomers such as vulcanized rubber materials are thermosets, which lead to processing and recycling problems [9]. However, block copolymers, which have rigid and elastomeric domains, also provide elastomeric properties. An example of such polymer is poly(styrene- $b$-butadiene- $b$-styrene), SBS. In this material the hard domains (polystyrene) act as physical cross links, while the segments of butadiene sequences form the elastomer phase, providing high chain mobility [7]. The crosslinking via vulcanization process is irreversible. However, in materials such as SBS, the intermolecular bonds that form the hard domains can be reversibly broken by heat. Therefore, these copolymers can be melted and solidified again, showing properties of thermoplastic elastomer. The commercially important elastomers have a block structure with $\phi$ high melting temperature or high glass transition temperature, which are the rigid blocks, combined with flexible segments. The former blocks comprise the hard domains that serve as a reinforcement and as cross-links, which are connected with the flexible blocks.

Another example of this advance is the development in the area of catalysts produced by Dow Chem. with the first patent in 2006 [10-14]. This new 
technology allows the production of new multiblock copolymers, using two catalysts with different capacities for the incorporation of comonomers, and adding a chain transfer agent that has the function to promote the exchange between the growing chains linked to each catalyst in a continuous reactor $[15,16]$.
The transfer agent (chain shuttling agent, CSA) refers to a compound or mixture of compounds that allows the transfer of chain fragments from different catalysts during polymerization (Scheme 1). The most suitable compound is diethyl zinc, which has been used as CSA [17-20].

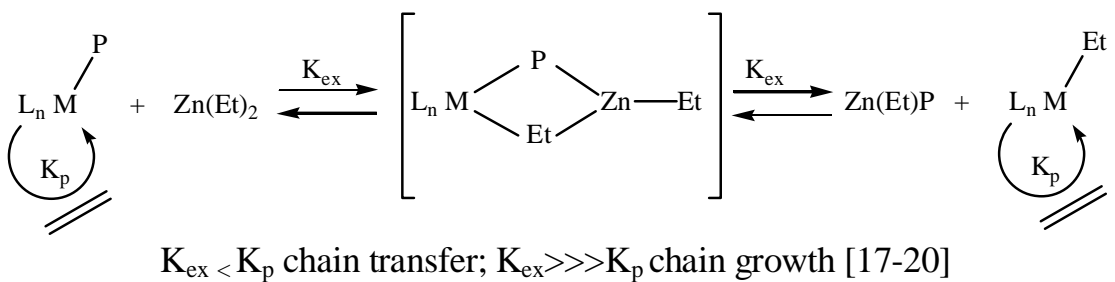

Scheme 1

The synthesized multiblock copolymer consists of blocks of crystalline ethylene/ $\alpha$-olefin (low commoner content and high of $T_{m}$ ) alternating with amorphous blocks (high comonomer content and low $T_{m}$ ) [21,22].

The present paper describes the synthesis of ethylene homopolymer consisting of blocks with amorphous and crystalline chain segments derived from a binary catalyst mixture comprising a nickel catalyst with $\alpha$-diimine ligand able to converting ethylene in a highly branched polyethylene (flexible PE) and a metallocene catalyst, the rac-ethylene bis $\left(\mathrm{H}_{4}\right.$-indenyl $) \mathrm{ZrCl}_{2}$, which produces polyethylene with a high linearity and melting temperatures (hard PE). Besides the evaluation of the influence of polymerization temperature $(333,353$ and $373 \mathrm{~K}$ ), the concentration of $\mathrm{Et}_{2} \mathrm{Zn}$ as a chain transfer agent was also varied.

\section{Experimental}

\subsection{M aterials}

All reagents were manipulated under inert atmosphere of nitrogen using the Schlenk technique. Ethylene and nitrogen were purified by sequential passage through columns containing $4 \mathrm{~A}$ molecular sieves and a copper catalyst to remove oxygen, carbon dioxide, and moisture. Toluene was refluxed over metallic sodium/ benzophenone and was distilled under nitrogen atmosphere prior to use. Methylaluminoxane (MAO) (10 wt \% solution in toluene, obtained from Chemtura, Germany), diethyl zinc was obtained from Akzo Nobel, Brazil, and used as received. The commercial catalyst racethylene bis $\left(\mathrm{H}_{4}\right.$-indenyl $) \mathrm{ZrCl}_{2}$ obtained by Witco TA 028 was used without further purification.

The ligand $N$-(2,6 diisopropylphenyl) imino] acenaphthene and the catalyst $\left({ }_{i} \mathrm{Pr}_{2} \mathrm{Ph}\right)_{2}$ bis(imino) acenafteno $\cdot \mathrm{NiBr}_{2}$ were prepared according to published procedures in the literature [23]. All other chemicals were commercial materials and were used as received.

\subsection{Synthesis of Ligand and Complex}

\subsection{1. [N-(2,6-Diisopropylphenyl)imino] acenaphthene}

2,6-Diisopropylaniline $(4.2 \mathrm{ml}, 22 \mathrm{mmol})$ was added to a solution of acenaphthenequinone (2 g, $11 \mathrm{mmol}$ ) in $25 \mathrm{ml}$ of ethanol. After the addition of a few drops of glacial acetic acid, the solution was refluxed during $4 \mathrm{~h}$. It was then cooled to room temperature and the solid filtered to give a yellow product that was washed with cold ethanol and air dried. Yield $4.7 \mathrm{~g}(85.5 \%)$. IR $\left(\mathrm{cm}^{-1}\right): 1673$ e $1653\left(v_{\mathrm{C}=\mathrm{N}}\right)$ e NMR $\left\{{ }^{1} \mathrm{H}\right\}(\delta \mathrm{ppm}): 0.98(\mathrm{~d}$, $12 \mathrm{H}) ; 1,24(\mathrm{~d}, 12 \mathrm{H}) ; 3.03(\mathrm{~m}, 4 \mathrm{H}) ; 6.64(\mathrm{~d}, 2 \mathrm{H}) ; 7.36(\mathrm{dd}$, $2 \mathrm{H}) ; 7.88(\mathrm{~d}, 2 \mathrm{H}) .{ }^{13} \mathrm{C}-\mathrm{NMR}(\delta \mathrm{ppm})\left(\mathrm{CDCl}_{3},{ }^{1} \mathrm{H}\right.$ gated decoupled): $161.1(\mathrm{C}=\mathrm{N}), 148.0\left(\mathrm{Ar}-C_{\mathrm{ip}}\right), 141.2,135.5$ $\left(\mathrm{Ar}-C_{\mathrm{p}}\right), 131.6,130.0,129.2,128.3,124.6,123.9,123.5$ $\left(\mathrm{Ar}-C_{\mathrm{m}}\right), 29.1(\mathrm{~N}=\mathrm{C}-\mathrm{Me}), 23.2(\mathrm{CHMe}), 23.1\left(\mathrm{CHMe}_{2}\right)$

\subsection{2. [N-(2,6-Diisopropylphenyl)imino] acenaphthene- $\mathrm{N} \mathrm{iBr}_{2}$}

$\mathrm{NiBr}_{2}(\mathrm{DME}) \quad(0.3 \mathrm{~g}, \quad 0.96 \mathrm{mmol})$ and $N-(2,6$ diisopropylphenyl)imino]acenaphthene $(0.5 \mathrm{~g}, 1 \mathrm{mmol})$ were added in $15 \mathrm{ml}$ of $\mathrm{CH}_{2} \mathrm{Cl}_{2}$, producing a red brown solution and a yellow solid. The mixture was stirred at room temperature for $16 \mathrm{~h}$, producing a brown solution. Then the solvent was evaporated yielding brown oil. After addition of $15 \mathrm{ml}$ of cyclohexane a brown precipitate was obtained, filtrated and dried in vacuo. Yield: $0.6 \mathrm{~g} \mathrm{(83 \% ).}$ IV (CsI, cm $\left.{ }^{-1}\right)$ : 1649, $1620(\mathrm{C}=\mathrm{N}), 279,258(\mathrm{Ni-Br})$ Anal. Calc. for $\mathrm{C}_{36} \mathrm{H}_{40} \mathrm{~N}_{2} \mathrm{Cl}_{2} \mathrm{Ni}$ : C, 68.6; H, 6.35; N, 4.45 . Found: C, 69.8; H, 7.8; N, 4.26

\subsection{Polymerization}

Ethylene polymerization was carried out in a jacketed Büchi glass reactor of $1000 \mathrm{ml}$ capacity, equipped with mechanical stirring and thermostatic bath for temperature control. Reactions were carried out under the following conditions: $100 \mathrm{ml}$ of distilled toluene, ethylene $\left[\mathrm{C}_{2} \mathrm{H}_{4}\right]=0.135 \mathrm{M}$, catalyst (metal) concentration 
$[\mathrm{Me}]=2 \cdot 10^{-4} \mathrm{M}$; cocatalyst methylaluminoxane $(\mathrm{MAO})$ $(\mathrm{Al} / \mathrm{Me}=200), 1 \mathrm{~h}$. Three temperatures $(333,353$ and $373 \mathrm{~K}$ ) and different concentrations of CSA (chainshuttling agent) $\left(\left[\mathrm{Et}_{2} \mathrm{Zn}\right] /\left[\mathrm{C}_{2} \mathrm{H}_{4}\right]\right)$ were evaluated.

The catalyst activity (catalyst efficiency) was calculated in tons of polymer produced per mol of transition metal, mol of ethylene, hour $(\mathrm{t} / \mathrm{molMe} \cdot \mathrm{molE} \cdot \mathrm{h})$, where: molMe $=$ number of moles of a catalyst $(\mathrm{Me}=\mathrm{Zr}$ or $\mathrm{Ni}$ ) in the reaction; $\mathrm{molE}=$ number of moles of ethylene in the reaction. The reaction time was $30 \mathrm{~min}$. The concentration of ethylene dissolved in the reaction medium was calculated using the state equation, considering the values of critical temperature, critical pressure and compressibility factor $(w)$. The number of moles of ethylene in $100 \mathrm{ml}$ of toluene is $0.135 \mathrm{M}$ at 200 , 260 and $300 \mathrm{kPa}$ for 333,353 and $373 \mathrm{~K}$, respectively [24].

\subsection{Characterization}

Polymers were characterized by density measurements using the pycnometer method; differential scanning calorimetry (DSC) was used to determine the thermal properties and degree of crystallinity; X-ray diffraction analyses were performed to obtain the materials crystallinity; dynamic mechanical analysis (DMA) was also employed to evaluate the storage $(E)$ and loss $\left(E^{\prime \prime}\right)$ moduli of the polymers produced, as well as the damping factor (tan delta) and glass transition temperature $(T g)$. For the characterization of the synthesized ligand and catalyst complex, ${ }^{1} \mathrm{H}$ - and ${ }^{13} \mathrm{C}$-NMR spectra were measured in a Varian Inova-300 MHz, IR-spectra were obtained in Nicolet equipment, model Magna-IR 760. Elemental analysis was performed on Perkin-Elmer 2400 Series II CHN/O Analyzer.

\section{Results and Discussion}

\subsection{Catalytic Activity}

The results of ethylene polymerizations are listed in Tables 1 and 2. Scheme 2 illustrates the molecular structures of the catalysts involved.

Fig. 1 shows the relationship between temperature and catalytic efficiency. It is observed that the activities of Cat 1 and Cat 2 at $333 \mathrm{~K}$ were equal, while the efficiency of the catalyst mixture was slightly lower. At the temperature of $353 \mathrm{~K}$, the efficiency of Cat1 was lower compared to Cat 2 , which activity increased by a factor of about 6 times, however there was a significant decrease in the activity of the catalyst mixture. Moreover, at $373 \mathrm{~K}$ the efficiency of the Cat 1 was even lower compared with other temperatures, while Cat 2 maintained high activity and the binary mixture remained practically unchanged compared to the result to $353 \mathrm{~K}$. It can be concluded that Cat 1 decreases its activity with increasing temperature, while Cat 2 is more thermally stable and has a higher activity at elevated temperatures.

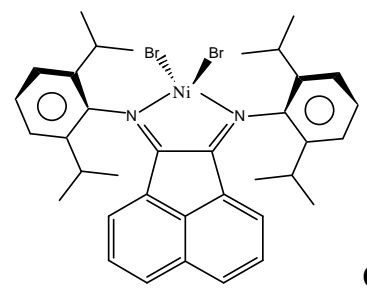

Cat 1

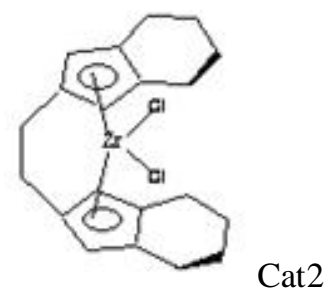

Scheme 2

Table 1

Characteristics of polymerization and catalyst efficiency

\begin{tabular}{|c|c|c|c|c|c|c|}
\hline \multirow{3}{*}{$\begin{array}{c}\text { Entry } \\
\text { (a) (b) (c) }\end{array}$} & \multirow{3}{*}{ Description } & \multirow{3}{*}{ Catalyst } & \multirow{3}{*}{$\begin{array}{c}{\left[\mathrm{Et}_{2} \mathrm{Zn}\right] /\left[\mathrm{C}_{2} \mathrm{H}_{4}\right]} \\
\left(10^{3}\right)\end{array}$} & \multicolumn{3}{|c|}{ Catalytic activity* } \\
\hline & & & & \multicolumn{3}{|c|}{ Temperature, $\mathrm{K}$} \\
\hline & & & & 333 (a) & 353 (b) & $373(\mathrm{c})$ \\
\hline 1 & soft PE & Cat1 & \multirow{3}{*}{0} & 43 & 33 & 11 \\
\hline 2 & hard PE & Cat2 & & 43 & 210 & 214 \\
\hline 3 & blend & Cat1+Cat2 & & 29 & 23 & 22 \\
\hline 4 & [1] CSA & \multirow{5}{*}{ Cat $1+$ Cat $2+\mathrm{Et}_{2} \mathrm{Zn}$} & 2 & 56 & 37 & 28 \\
\hline 5 & [2] CSA & & 4 & 40 & 35 & 22 \\
\hline 6 & [3] CSA & & 6 & 142 & 118 & 68 \\
\hline 7 & [4] CSA & & 8 & 168 & 132 & 102 \\
\hline 8 & [5] CSA & & 10 & 107 & 59 & 53 \\
\hline
\end{tabular}

*t/molMe-molE·h 
Polyethylene physical properties

\begin{tabular}{|c|c|c|c|c|c|c|c|c|c|c|}
\hline \multicolumn{2}{|c|}{ Polymer } & \multirow{2}{*}{$\begin{array}{c}\text { Density, } \\
\mathrm{g} / \mathrm{cm}^{3}\end{array}$} & \multirow{2}{*}{$\begin{array}{c}T_{m} \\
\mathrm{~K}\end{array}$} & \multirow{2}{*}{$\begin{array}{c}T_{c}, \\
\mathrm{~K}\end{array}$} & \multirow{2}{*}{$\underset{\mathrm{o}}{T_{m}-T_{c},}$} & \multirow{2}{*}{$\begin{array}{c}\Delta H_{m}^{\mathrm{a}}, \\
\mathrm{j} \cdot \mathrm{g}^{-1}\end{array}$} & \multirow{2}{*}{$\begin{array}{c}\Delta H_{m}{ }^{\mathrm{b}}, \\
\mathrm{j} \cdot \mathrm{g}^{-1}\end{array}$} & \multirow{2}{*}{$\begin{array}{c}X_{c}^{\mathrm{c}}, \\
\%\end{array}$} & \multirow{2}{*}{$\begin{array}{c}X_{C A H}^{\mathrm{d}}, \\
\%\end{array}$} & \multirow{2}{*}{$\begin{array}{c}X_{c}^{\mathrm{e}}{ }_{\text {WAXD }} \\
\%\end{array}$} \\
\hline$T, \mathrm{~K}$ & code & & & & & & & & & \\
\hline \multirow{8}{*}{333} & $1 \mathrm{a}$ & 0.8702 & - & - & - & - & - & - & - & - \\
\hline & $2 \mathrm{a}$ & 0.9351 & 404 & 394 & 10 & 220 & 162 & 59 & 55 & 53 \\
\hline & $3 \mathrm{a}$ & 0.8856 & 403 & 390 & 13 & 51 & 30 & 23 & 10 & 27 \\
\hline & $4 \mathrm{a}$ & 0.9162 & - & - & - & - & - & - & - & - \\
\hline & $5 \mathrm{a}$ & 0.8716 & 400 & 378 & 22 & 9 & 6 & 13 & 2 & 15 \\
\hline & $6 \mathrm{a}$ & $\begin{array}{l}0.8677 \\
\end{array}$ & 400 & 384 & 16 & 7 & 4 & - & 1.5 & - \\
\hline & $7 \mathrm{a}$ & 0.9013 & 404 & 387 & 17 & 147 & 114 & 36 & 39 & 53 \\
\hline & $8 \mathrm{a}$ & 0.8641 & 403 & 385 & 18 & 10 & 6 & - & 2 & - \\
\hline \multirow{8}{*}{353} & $1 \mathrm{~b}$ & 0.8594 & - & - & - & - & - & - & - & - \\
\hline & $2 \mathrm{~b}$ & 0.9334 & 406 & 396 & 10 & 224 & 155 & 57 & 52 & 49 \\
\hline & $3 \mathrm{~b}$ & 0.9085 & 405 & 391 & 14 & 179 & 149 & 41 & 50 & 45 \\
\hline & $4 \mathrm{~b}$ & 0.8594 & 402 & 353 & 50 & 10 & 0.5 & - & 0.02 & - \\
\hline & $5 \mathrm{~b}$ & 0.8893 & 403 & 385 & 18 & 34 & 24 & 26 & 8 & 26 \\
\hline & $6 \mathrm{~b}$ & 0.9229 & 405 & 389 & 16 & 172 & 155 & 51 & 57 & 63 \\
\hline & $7 \mathrm{~b}$ & 0.9169 & 405 & 390 & 15 & 188 & 168 & 47 & 55 & 67 \\
\hline & $8 \mathrm{~b}$ & $\begin{array}{l}0.8893 \\
\end{array}$ & 403 & 384 & 19 & 44 & 20 & 27 & 7 & 22 \\
\hline \multirow{8}{*}{373} & $1 \mathrm{c}$ & 0.8710 & - & - & - & - & - & - & - & - \\
\hline & $2 c$ & 0.9364 & 403 & 393 & 10 & 225 & 218 & 60 & 74 & 85 \\
\hline & $3 \mathrm{c}$ & 0.9150 & 404 & 392 & 12 & 156 & 141 & 45 & 50 & 49 \\
\hline & $4 \mathrm{c}$ & 0.8573 & 401 & 386 & 15 & 26 & 29 & 18 & 10 & 19 \\
\hline & $5 \mathrm{c}$ & 0.9238 & 405 & 390 & 15 & 145 & 143 & 51 & 49 & 50 \\
\hline & $6 \mathrm{c}$ & 0.8918 & 404 & 388 & 16 & 91 & 87 & 28 & 30 & 37 \\
\hline & $7 \mathrm{c}$ & 0.9320 & 403 & 387 & 16 & 188 & 177 & 57 & 60 & 75 \\
\hline & $8 \mathrm{c}$ & 0.9013 & 401 & 381 & 20 & 20 & 4 & - & 1.5 & - \\
\hline
\end{tabular}

Notes: ${ }^{a}$ first heating; ${ }^{b}$ second heating; ${ }^{c}$ crystallinity from density; ${ }^{d}$ crystallinity from heat of melting; ${ }^{\mathrm{e}}$ crystallinity from WAXD

However, interestingly the catalytic mixture has not the expected behavior, but their activity was similar to that of Cat1. Therefore, the performance of the catalyst mixture was different from that of the isolated systems, showing that there was interference between catalytic systems in the polymerization of ethylene in the presence of MAO.

The influence of CSA concentration in the polymerization using mixture of Cat 1 and Cat 2 at 333, 353 and $373 \mathrm{~K}$ was investigated. Fig. 2 shows the relationship of the used CSA concentrations and the efficiencies obtained in the catalytic polymerization of ethylene. Initially it was observed that the activities of the catalysts in the three reaction temperatures responded similarly to the presence of chain transfer agent (CSA). At $333 \mathrm{~K}$ and in all concentrations of CSA the binary catalyst efficiency showed a higher value than that at increased temperatures. In fact, for the catalyst mixture, the increase in polymerization temperature led to the decreased activity. On the other hand, it was observed that there was a significant increase in yield with increasing concentration of CSA in the reaction medium. The major activities can be observed in the molar ratios of $\left[\mathrm{Et}_{2} \mathrm{Zn}\right] /\left[\mathrm{C}_{2} \mathrm{H}_{4}\right]=6 \cdot 10^{-3}$ and $8 \cdot 10^{-3}$. Above this concentration of $\mathrm{ZnEt}_{2}$ there was a decrease in activity at the three evaluated polymerization temperatures.

The study of the activity in binary systems in the presence of non-metal alkyl compound has not been fully understood. Tynys et al. [25] and Chien et al. [26] observed the increased activity in a mixture of catalysts in the presence of trimethylaluminum (TMA) and triisobuthylaluminum (TIBA), respectively. While Bastos et al. [27] reported a decrease in catalytic activity in binary systems also using TIBA. The increased activity could mean that reversible chain transfer is occurring. A catalyst could act continuously consuming the product of chain termination on the other catalyst, leading to the increased activity. This mechanism explains the results observed in the binary catalyst system of the present study. On the other hand, the reason for the decrease in catalytic efficiency with the excess $\mathrm{ZnEt}_{2}$ was proposed by Bruaseth and Rytter [28].

According to those authors, the product of polymer chain termination by chain transfer with the metal alkyl compound can remain coordinated with the active catalyst, resulting in decreased activity at high CSA concentrations. 


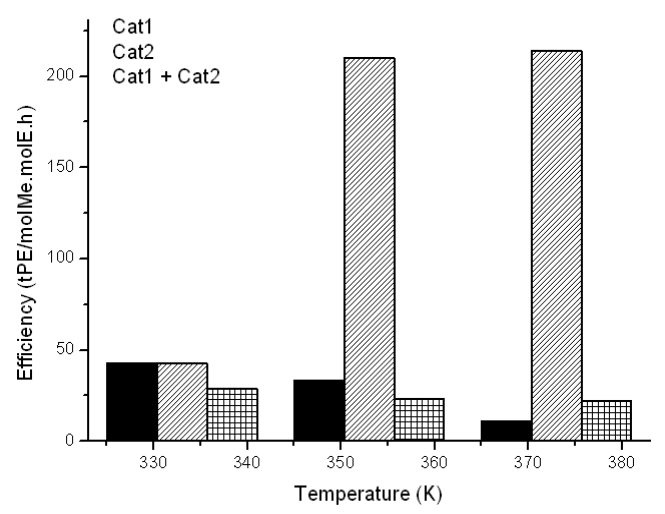

Fig. 1. Relationship between catalytic efficiency and temperature

\subsection{Crystalline Structure}

The WAXD profiles for the polymers synthesized at 333, 353 and $373 \mathrm{~K}$ are shown in Fig. 3 (a, b and c, respectively). This shows the XRD patterns of the polymers synthesized with the two catalysts acting isolated with and without the transfer agent $\mathrm{ZnEt}_{2}$. For most samples, the peaks at $2 \theta$ of $21.5^{\circ}$ and $23.9^{\circ}$ were designated as (110) and (200) to equivalent structures of the crystallographic planes of the orthorhombic unit cell of polyethylene.

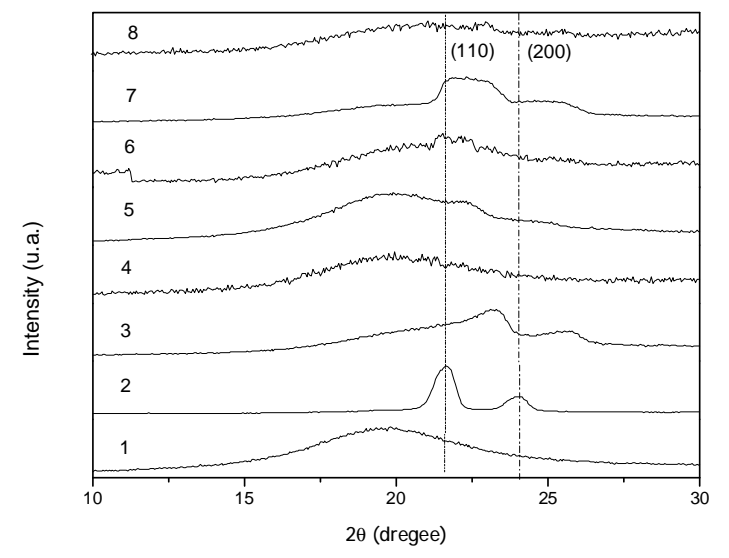

a)

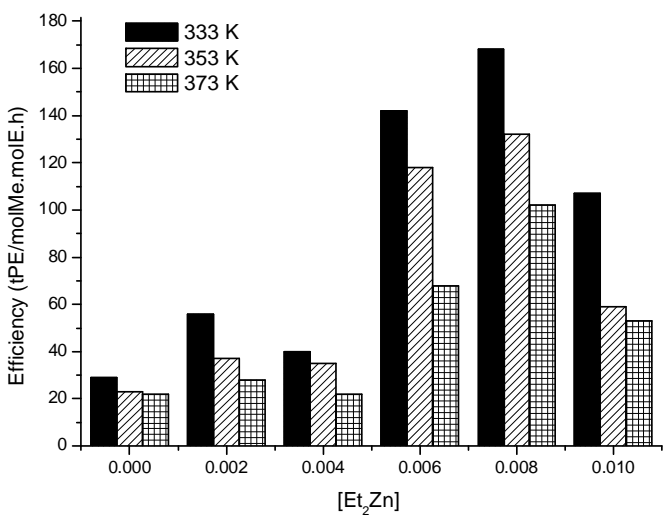

Fig. 2. Relationship between catalytic efficiency and $\left[\mathrm{Et}_{2} \mathrm{Zn}\right] /\left[\mathrm{C}_{2} \mathrm{H}_{4}\right]$

While the Cat1 produces amorphous polymer in all reaction temperatures, as shown in the XRD patterns $1 \mathrm{a}, 1 \mathrm{~b}$ and $1 \mathrm{c}$, where the amorphous PE halos appear, Cat 2 produces crystalline PE (patterns $2 \mathrm{a}, 2 \mathrm{~b}$ and $2 \mathrm{c}$ ). Since the binary catalyst without CSA produces less crystalline $\mathrm{PE}$, indicated by the broadening of the crystalline peak, it is possible that this polymer consists of a mixture of polyethylenes synthesized by both catalytic systems. The mixture of crystalline and amorphous PE decreased the overall crystallinity of the PE obtained.

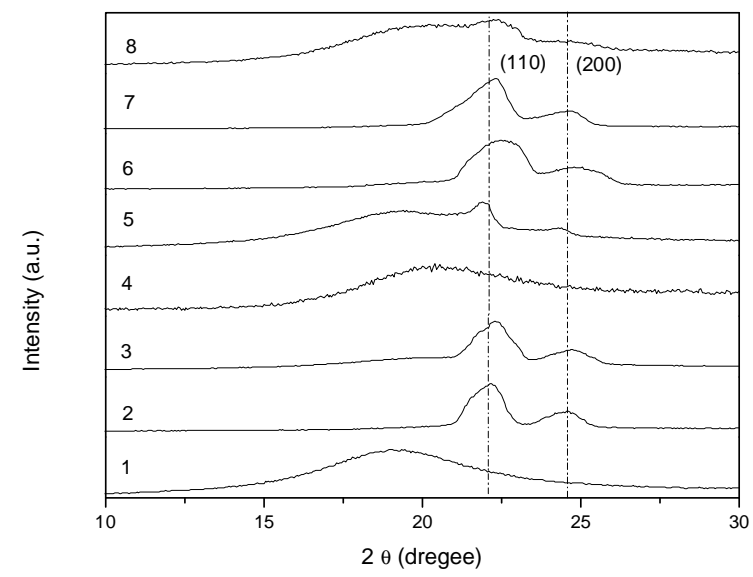

b)

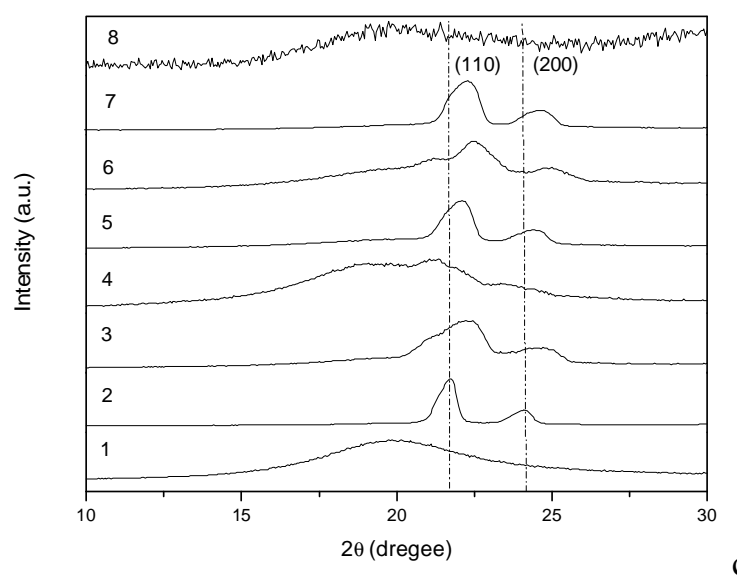

c)

Fig. 3. Diffractograms of polyethylenes synthesized at: $333 \mathrm{~K}$ (a), $353 \mathrm{~K}$ (b) and $373 \mathrm{~K}$ (c) 
On the other hand, the displacement of the reflection peaks corresponding to the crystallinity of the PE mixture obtained with CSA (diffractograms 6b, 6c, 7b and $7 \mathrm{c}$ in Fig. 3) may be explained by the increased amount of soft segments in the polymer chain. Thus, the unit cell undergoes an orthorhombic distortion due to the presence of branches in the polymer chain - orthorhombic reflections (110) and (200) remain, but the intensity decreases - while the extension of the halo is due to the reduction of rigid segments, as shown in Fig. 3. However, the distortion was much lower in polyethylene synthesized at $373 \mathrm{~K}$ (Fig 3c). The diffraction peaks of the orthorhombic unit cell were dilated for all PE samples produced with catalytic mixture in the presence of CSA. This fact became even more pronounced with the presence of high amount of CSA, which may indicate the presence of soft and hard blocks in the polymer chain. It can be observed that at $333 \mathrm{~K}$ the profiles of the PE obtained with the binary catalyst resemble the profile of the polymer synthesized with Cat1, which produces the amorphous polymer, indicating the high activity of this system at this temperature. Already at $373 \mathrm{~K}$ the polymers have the profile of sample 2 synthesized with Cat 2 which produces crystalline polyethylene, this was due to the fact that Cat1 has the decreased activity at high temperature. The XRD patterns of the polymers obtained at $353 \mathrm{~K}$ in the presence of CSA suggests the presence of soft and hard domains in the same polymer chain. The profiles have the most outstanding changes in samples 6 and 7 at $[\mathrm{Zn}] /\left[\mathrm{C}_{2} \mathrm{H}_{4}\right]=6 \cdot 10^{-3}$ and $8 \cdot 10^{-3}$. We can estimate the degree of crystallinity of the samples through the areas of crystalline peaks and amorphous halo, using Eq. (1) [29].

$$
\% X_{c}=\frac{A_{c}}{A_{c}+A_{a}}
$$

where: $A_{c}$ - area on the crystalline peak; $A_{a}-$ area on the amorphous halo.

The results presented in Table 2 for the degree of crystallinity of the polyethylene obtained showed a good correlation with the other determinations of crystallinity.

Morphological studies have shown that long sequences of ethylene in rigid olefin block copolymers can crystallize in the form of lamellar crystals with few defects and high melting temperatures, featuring the hard segments.

The crystalline phase acts as the reinforcement to train physical nodes, connecting with the elastomeric chains (soft segments) [30]. The trend line gives us the coefficient of determination/correlation $(R)$, an indicator ranging from 0 to 1 and reveals the closeness of the estimated values of the trend line in correspondence with the veracity of the data. The reliability of the linear trend is given when the value of $R$ is equal or close to 1 . Fig. 4 illustrates the relationship between $X_{c}$ values calculated by DSC and WAXD with the value of $R=0.9647$.

In general the values of $X_{c}$ obtained by DSC are lower, which can be explained by different factors. One is that the X-ray scattering is sensitive to organized structures at the nanometer scale, not only crystal structures.

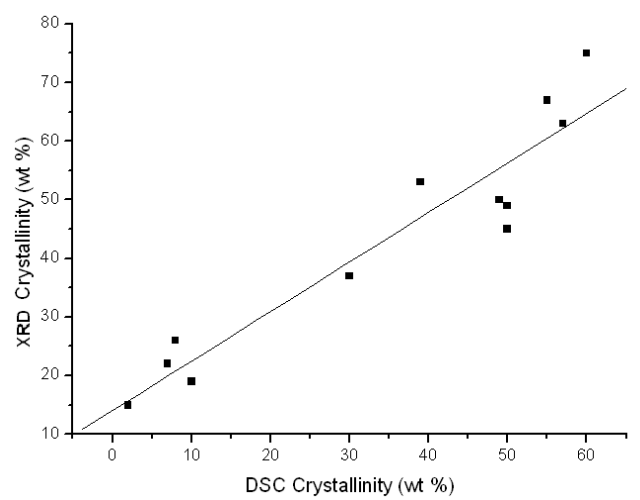

Fig. 4. Relationship between crystallinity $\left(X_{c}\right)$ measured by XRD and DSC

Another factor is that lamellar crystals of different thicknesses have different melting enthalpies, as a result of different entropies of fusion. Therefore, samples with relatively small crystals have underestimated their crystalline fractions by DSC [31].

\subsection{Thermal Behavior}

The thermograms of first heating, cooling and subsequent heating for polymers synthesized at 333, 353 and $373 \mathrm{~K}$ are shown in Figs. 5-7, respectively. All polymers synthesized presented high melting $\left(T_{m}\right)$ and crystallization $\left(T_{c}\right)$ temperatures, with exception of the samples synthesized with Cat1, which produces amorphous PE. The results of the melting temperatures $\left(T_{m}\right)$, crystallization $\left(T_{c}\right)$ and melting enthalpies $\left(\Delta H_{m}\right)$ for the first and second heating are shown in Table 2. The values of $T_{m}$ showed slight variation in the PE synthesized with the addition of transfer agent, which can be observed in the DSC thermograms by the peak shift to lower temperatures, justifying the reduction of rigid sequences. The main effect caused by the composition of flexible and rigid segments in the chain was shown by the decrease of the transition enthalpies $\left(\Delta H_{m}\right)$. According to Wang et al. [21], the increased values of the melting enthalpies $\left(\Delta H_{m}\right)$ observed from the first heating, means an increase in the amount of crystallizable blocks.

The polymers synthesized with Cat1, samples 1, 2 and 3 have the following values of $T_{m}: 404,406$ and $403 \mathrm{~K}$, respectively. The samples obtained by the binary catalytic without CSA revealed the values of $T_{m}: 403,405$ and $404 \mathrm{~K}$, showing that there was no influence on the $T_{m}$ of polymers.

On the other hand, the presence of CSA at different concentrations revealed that the synthesized polyethylene at $333 \mathrm{~K}$ resulted in $T_{m} 3$ degrees lower as compared to the polymers synthesized 353 and $373 \mathrm{~K}$. With increasing content of the flexible blocks, the melting peak of the rigid blocks slightly shifts, as shown in Figs. 5-7. 

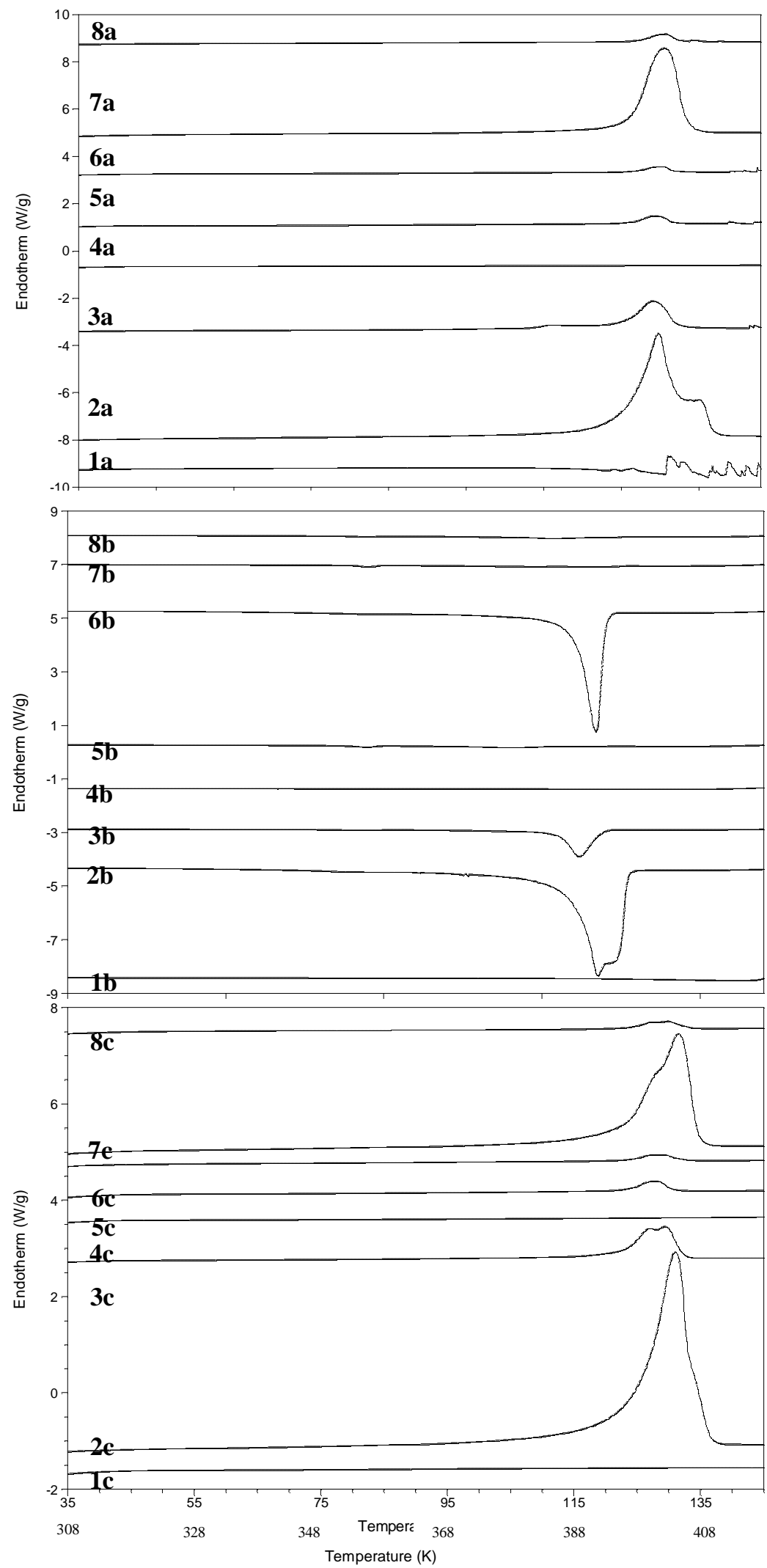

Fig. 5. Thermal behavior of polymers produces at $333 \mathrm{~K}$ : first heating thermograms (a); cooling thermograms (b) and second heating thermograms (c). The heating/cooling rate was $10 \mathrm{deg} \mathrm{min}^{-1}$ 

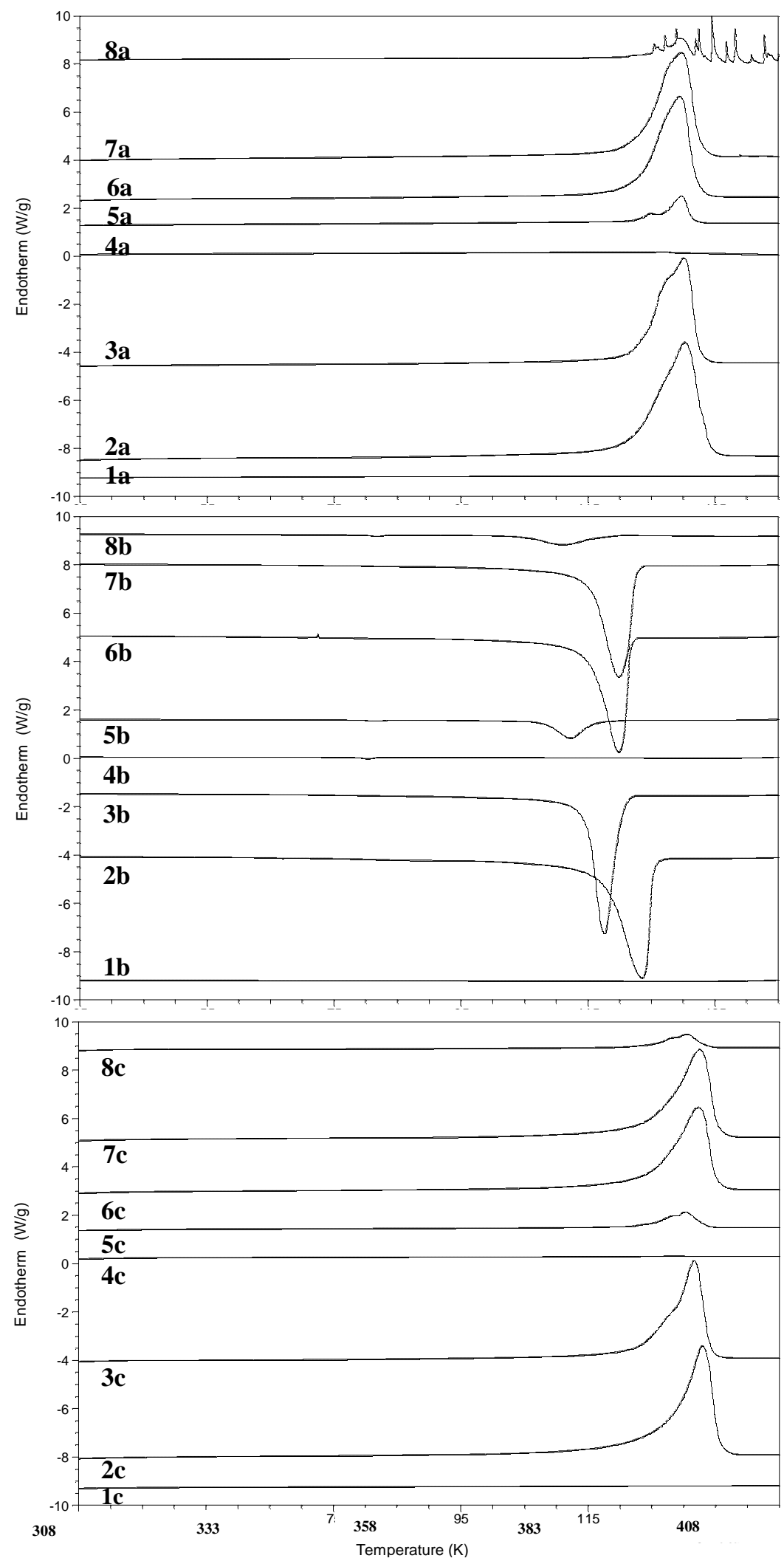

Fig. 6. Thermal behavior of polymers produces at $353 \mathrm{~K}$ : first heating thermograms (a); cooling thermograms (b) and second heating thermograms (c). The heating/cooling rate was $10 \mathrm{deg} \mathrm{min}^{-1}$ 

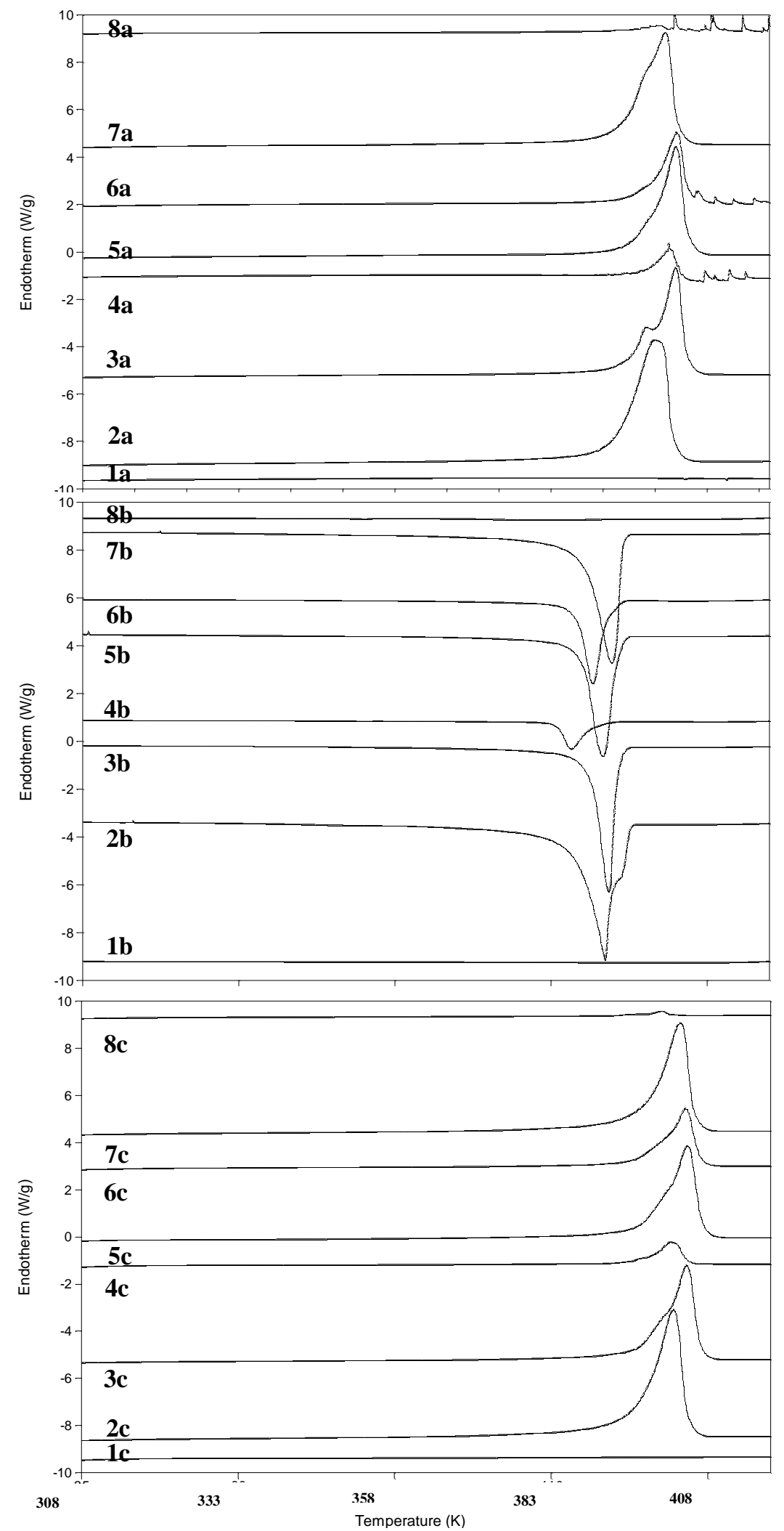

Fig. 7. Thermal behavior of polymers produces at $373 \mathrm{~K}$ : first heating thermograms (a); cooling thermograms (b) and second heating thermograms (c). The heating/cooling rate was $10 \mathrm{deg} \mathrm{min}^{-1}$ 
Small changes in $T_{c}$ parallel to the decrease in $T_{m}$ results in subcooling $\left(T_{m}-T_{c}\right)$, which in this case were about 15 to 20 degrees for all polymers synthesized, except for the sample $4 \mathrm{~b}$, that showed an unexpected behavior with a difference of 50 degrees, revealing a higher concentration of flexible blocks. With this obtained data it can be observed that the polymer block has two contributions of both structures, from the amorphous phase (flexible block) and hard crystalline block.

\section{Conclusions}

The characterization of solid-state structure and properties of block polymers of ethylene synthesized in this work showed that they relate to the concept of thermoplastic elastomer in which crystallizable blocks serve as physical cross-links connecting amorphous blocks. In the dynamic mechanical properties the CSA promoted decrease in the hard segments in the chains of the copolymers obtained by catalytic mixtures, however, high concentrations of CSA was the increase of the material modulus.

In addition, we observed that the efficiency of the Cat1 decreased at high temperature polymerization and this produced amorphous $\mathrm{PE}$. The addition of $\mathrm{Et}_{2} \mathrm{Zn}$ increased efficiency for the binary mixture from the ratio $[\mathrm{Zn}] /[\mathrm{Et}]=6 \cdot 10^{-3}$ and $8 \cdot 10^{-3} \mathrm{M}$, as had been previously reported [33], this mixture showed the formation of the PE block - the hard and soft one. Increasing the temperature of polymerization, as well as $[\mathrm{Zn}]$ produced $\mathrm{PE}$ with higher $T_{m}$ and $X_{c}$ which reveals the low thermal resistance of Cat1 which produces the soft segment.

\section{Acknowledgments}

The authors thank CAPES, CNPq and Petrobras.

\section{References}

[1] Hustad P.: Science, 2009, 325, 704.

[2] Galli P. and Vecellio G.: Program Polym. Sci., 2001, 26, 1287.

[3] Mitani M., Saito J., Ishii S., Nakayama Y., Makio H., Matsukawa N., Matsui S., Mohri J., Furuyama R., Terao H., Bando

H., Tanaka H., Fujita T.: The Chem. Rec., 2004, 4, 137.

[4] Beigzadeh D., Soares J. and Duever T.: Macromolecular Symposia, 2001, 173, 179.

[5] Krevelen D. and Nijenhuis K.: Properties of Polymers: their Correlation with Chemical Structure, their Numerical Estimation and Prediction from Additive Group Contributions; Copyright $4^{\text {th }}$ edn, Elsevier, Amsterdam 2009.

[6] Kaminsky W.: Macromol. Chem. Physics, 2008, 209, 459.

[7] Caprio M., Serra M., Bowen D. and Grassi A.: Macromolecules, 2002, 35, 9315

[8] Mano E. and Mendes L.: [in:] Blücher E.: (Ed.) Introdução a polímeros, $2^{a}$ edição. São Paulo 1999, 92-93.

[9] Murillo R., Ayllón E., Navarro M. et al.: Fuel Proc. Technol., 2006, 87, 143.

[10] Hustad P., Kuhlman R., Arriola D. et al.: Macromolecules, 2007, 40, 7061 .

[11] Hiltner A., Wang H., Khariwala D. et al.: $64^{\text {th }}$ Annual Technical Conference - SPE, USA, Charlotte 2006, 1000.

[12] Arriola D., Devore D., Carnahan E. et al: Pat. USA WO 2005/090425 A1, Publ. Sep. 29, 2005.
[13] Arriola D., Devore D., Carnahan E. et al.: Pat. USA WO 2005/090427 A2, Publ. Sep. 29, 2005.

[14] Arriola D., Carnahan E., Cheung Y. et al.: Pat. USA 2007/0167578 A1, Publ. Mar. 17, 2005.

[15] Tynys E., Eilertsen J., Seppällä J., Rytter E.: J. Polym. Sci. A, 2007, 45, 1364.

[16] Kuhlman, R.L., Wenzel, T.T.: Macromolecules, 2008, 41, 4090.

[17] Arriola D., Carnahan E., Bokota M. et al.: Pat. USA WO 2006/101597, Publ. Sep. 28, 2006.

[18] Gibson V.C.: Science, 2009, 312, 703.

[19] Pan L., Zhang K., Nishiura M. and Hou Z.: Angew. Chem. Int. Ed., 2011, 50, 1.

[20] Zhang M., Karjala T., Jain P.: Ind. Eng. Chem. Res. 2010, 49, 8135.

[21] Wang H., Khariwala D.U., Cheung W., Chum, S.P.; Hiltner, A.; Baer, E.: Macromolecules, 2008, 40, 2852.

[22] Khariwala D., Taha A., Chum S., Hiltner A., Baer E.: Polymer, 2008, 49, 1365.

[23] Merna J., Hoštálek Z., Peleška J., Roda J.: Polymer, 2009, 50, 5016.

[24] Moraes S.: PhD thesis, Instituto de Macromoléculas Professora Eloisa Mano, UFRJ, Rio de Janeiro 2009.

[25] Tynys, E., Eilertsen, J.L., Seppällä, J.V., Rytter, E.: J. Polym. Sci. A, 2007, 45, 1364.

[26] Chien J., Iwamoto Y. and Rausch M.: J. Polym. Sci. A, 1999, 37, 2439 .

[27] Bastos Q. and Marques M.F.V.: J. Polym. Sci. A, 2005, 43, 263.

[28] Guan Z.: Metal catalysts in olefin polymerization. Topic in Organometallic Chemistry. Springer, Berlin-Heidelberg 2009.

[29] Canevarolo S.: Técnicas de caracterização de polímeros. São Carlos-SP, 2007.

[30] Zuo F., Burger C., Chen X. et al.: Macromolecules, 2010, 43, 1922.

[31] Crist B. and Mirabella F.: J. Polym. Sci. B, 1999, 37, 3131.

[32] Wang H., Taha A., Chum S. et al.: http://www.dow.com/ infuse/lit/ índex.htm.

[33] Britovsek G., Cohen S., Gibson V. et al.: Angew. Chem. Int. Ed., 2002, 41, 489.

\section{ПОЛІМЕРИЗАЦІЯ ЕТИЛЕНУ 3 КАТАЛІТИЧНОЮ СУМІШШЮ В ПРИСУТНОСТІ ЛАНЦЮГОВОГО ШАТЛ-АГЕНТУ}

Анотація. Показано можливість поєднання мікроструктур каталізаторів в каркасі полімеру внаслідок змішування двох каталізаторів в реакторі, де відбувається кополімеризачія ети-

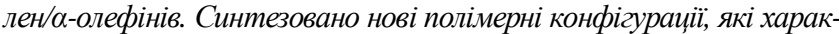
теризуються послідовністю мономерів, отриманих з кожним із каталізаторів в одному полімерному ланщюзі. Додавання реагента зворотнього переходу (РЗП) до бінарної системи дає можсливість одержати нові блок-кополімери з покращеними властивостями. Каталізатори на основі перехідних металів, такі як $\alpha$-дііміннікелевий каталізатор, активізований метилалюмооксаном, виявляють високу активність по відноменню до полімеризачіі олефінів $і$ дають можливість отримувати високорозгалужені гомополімери. $C_{2}$-симетричні металлоченові каталізатори використовують для виробничтва лінійного поліетилену. Приведено методику синтезу гомополімеру етилену з аморфними і кристалічними блоками з використанням бінарної сумімі нікелевого каталізатора з $\alpha$-діімін лігандом для одержання високорозгалуженого поліетилену (м'який ПЕ) $i$ металлочену (раи-етиленбіс $\left(\mathrm{H}_{4}\right.$-інден) $\left.\mathrm{ZrCl}_{2}\right)$, який перетворюе етилен в поліетилен 3 високою активністю і температурою плавлення (жсорсткий ПЕ). Досліджено вплив температури полімеризаиії $і$ концентраиії РЗП. Визначено характеристики одержаних полімерів.

Ключові слова: полімеризаиія етилену, каталізатор, суміш каталізаторів, ланцюговий шатл-агент. 